\title{
Effect of Biostimulation with Organic Amendment on the Growth and Yield of Maize (Zea Mays) In Diesel Oil (Ago) Polluted Soil
}

\author{
Okechalu, O.B, Oke, F.M, Egbere, O.J and Juliet N. Okechalu. \\ Department of Plant Science and Technology University of Jos
}

\begin{abstract}
The effect of poultry manure and cow dung amendment of diesel oil polluted soil on the growth of Zea mays (Maize) was carried out in a green house at Lamingo area of Jos. The experiment was set up in a randomize block design (RBD) of five (5) replicates for each treatment. Loamy soil (500g) was polluted with $250 \mathrm{ml}$ of diesel oil in perforated polyethene bags size $(64 \times 21 \mathrm{~cm})$ and amended with poultry manure and cow dung at $0 \% .10 \%, 20 \%$ and $30 \%$ soil weight. Three (3) seeds of maize were planted in each pot. Two types of control were set up to validate this experiment: a positive control (500g of soil + Oml of diesel $+0 \%$ manure) and a negative control (500g of soil $+250 \mathrm{ml}$ diesel $+0 \%$ manure). These were observed for germination and growth parameters for 13 weeks. The results showed that maize seeds in the positive control had the shortest day to germination (6day), an average of 12 and 13 days to germination was observed in plots treated at $30 \%$ poultry manure and cow dung respectively. No germination was observed in both the negative control and at $10 \%$ organic manure treatment. Maize plants in the positive control plots had highest mean leaf count (13) followed by those at $30 \%$ manure treatment (11) and (12) respectively, while those at $20 \%$ manure treatment had the least number of leaves. Results on stem girth followed a similar trend with the aforementioned parameters. Plant height at weeks 10 and 12 were significantly higher than those of all other weeks, but do not differ from each other at 0.05 level of probability. Plant in the control had the highest number of kernels per cob (187) followed by plot at 30\% manure treatment 150 and 180 respectively for poultry manure and cow dung. The study has shown that diesel contamination affected growth and yield of maize plant adversely. However among the manure treated plots those exposed to higher fraction of poultry manure strived better than those treated with equal fraction of cow dung. Poultry manure can therefore be recommended as a biostimulant in diesel oil polluted soil.
\end{abstract}

\section{Introduction}

The earth has faced many disasters that have been caused by humans throughout history. One of the most important hazard jeopardizing our environment today is petroleum pollution which occurs as a result spills during extraction, processing, transportation and pipeline rust or damage (Yakubu, 2007)

Crude oil and petroleum products such as gasoline, fuel oil and diesel fuel are complex mixture of organic compounds and have been shown to be toxic to plants, in addition to their adverse effects on soil ecosystem through adsorption to soil particles (Anonymous, 2003).

In Nigeria most of the terrestrial ecosystem and shore lines in oil producing community are important agricultural land under cultivation. Any contact with crude oil usually results in damage to the soil, microorganism and plants (Adedokun \& Ataga, 2007). Agbogidi et al. (2005) reported that oil spillage constitute the most significant source of oil pollution in the Niger Deltal region of Nigeria. Oil spillage also destroys farmlands and has significant effect on plant growth.

Bioremediation's role is to optimize conditions for natural microbes to degrade environmental pollutant (Penny et al., 2003). There are two main approaches to oil spill bioremediation, which are; bioaugmentation and biostimulation (Yakubu, 2007).

Bioaugmentation deals with the use of beneficial microbes that have an affinity towards specific pollutants (Venosal et al., 1996; Mekec \& Mendelssilni, 1995). While biostimulation involves the aeration and addition of selected micronutrient and sometimes top soil to appropriate quantities (Shekwolo, 2005; Swannell et al., 1999) i.e the modification of the environment to stimulate exiting bacteria capable of bioremediation. The primary advantage of biostimulation to bioaugmentation is that bioremediation will be undertaken by already present native microorganism that are well suited to subsurface environment and are well distributed spartially within the subsurface (Mishra et al., 2001).

Maize (zea mays $\mathrm{L}, 2 \mathrm{n}=20$ ) is an important cereal crop of the world and household staple food in Nigeria, it has worldwide significance as human food, animal feed and as a raw material for the manufacture of hundreds of industrial product. These products include corn starch, matodexrins, corn flour, corn oil, corn syrup and products of fermenting and distilling industry, and is grown across the country (Nigeria) (Miracle, 1996).

There is a dire need to prevent, control and clean up hydrocarbon polluted soil. Although excavation and chemical treatment of the polluted soil seems the most definite measure, cost of such operations and damage to 
building and infrastructure prevents such an approach. It is against this background that this present work was designed with the aim of determining the efficacy of cow dung and poultry manure as biostimulants in soil polluted with diesel and to evaluate the response of maize on the soil.

\section{Materials And Methods}

The research was conducted in a green house located at Lamingo Shere Hills area of Jos East LGA of Plateau state, Nigeria between February to April, 2011. Jos is located on latitutde $9^{0} 52^{\prime} \mathrm{N}$ and on longitude $8^{0}$ $53^{\prime} \mathrm{E}$ has an equable climate averaging $22^{\circ} \mathrm{C}\left(75^{\circ} \mathrm{F}\right)$ daily, with an verage humidity of $60 \%$ and average annual rainfall $1400 \mathrm{~mm}(56 ")$.

Maize seeds were purchased from Angwa Rukuba market, the organic manure (cow dung and poultry manure) were collected from Jos abattoir and a poultry farm in Lamingo area respectively. The diesel oil was obtained from U.U.Martins fuel station at Yantrailer area of Jos North LGA of Plateau state.

Forty bottom perforated polyethene bags with a diameter of $64 \mathrm{~cm}$ and a depth of $21 \mathrm{~cm}$ were each filled with five hundred grams $(500 \mathrm{~g})$ of soil collected from a farm site at Lamingo area of Jos east LGA, 30 pots were used as the experimental pots in which the soil was mixed with $250 \mathrm{ml}$ of diesel oil (AGO) and were then treated with 10\%, 20\%,30\% soil weight of each manure respectively. i.e (Manure + diesel + soil). Two sets of control were used (i) A positive control $(0 \%$ manure $+0 \%$ diesel + soil $)$, (ii) a negative control $(0 \%$ manure $+250 \mathrm{ml}$ diesel + soil 500g).

This was left to stand for two weeks before seeding. The pots were then set up in a randomized complete block design with (8) treatment combinations i.e 2manure types, 3 fractions of each manure and two controls. Each treatment was replicated five (5) times. Three seeds of the corn (Zea mays) were sown in each polyethene bags at depths of $30 \mathrm{~cm}$, the pots were watered daily. Data on germination was recorded after 7 days; seed which failed to germinate after 14 days were regarded as having not germinated. Seedlings were thinned to one per poly pot at two weeks after sowing. The results were monitored for 104 days (14 weeks). The following growth parameters were observed; number of days to germination, germination percentage (\%), number of leaves, stem girth, plant height and number of cobs per plants were taken. After harvesting the number of kernels per cobs was taken. The data was subjected to analysis of varience (ANOVA) at 0.05 level of probability. Germination period was determined by observing the number of days to germination.

Percentage germination $=$ No of germinated seed $\mathrm{x} 100$

Total no of seed sown series

Number of leaves was by visual counting of the number of leaves per plant, the stem girth was measured with a measuring tape, measurement was taking at the second node from the base. Plant height was measure using a tape rule at a distance from soil level to the flag leaf. While number of cobs per plant was taking by counting the number of cop per plant and lastly the number of kernel per cob was determine by counting the number of cobs per kernel from each plant.

\section{Mean Days To Germination}

\section{Results}

The result revealed that maize sowed in the positive control plots germinated within six (6) days. While no germination was recorded in the "negative control' plots and plots treated with soil weight $10 \%$ manure respectively. Plots treated with $20 \%$ soil weight manure had an average of thirteen (10) days to germination for poultry manure and 13 days to germination for cow manure at $30 \%$ soil weight manure treatment, cow dung fertilized plant recorded an average of 11 days to germination, while poultry manure treated plants recorded 8 days to germination (Fig 1).

\section{Germination count}

The result showed that the positive control (pots without diesel pollution) had the highest germination count with a percentage of $99.6 \%$, followed by seeds sown in $30 \%$ manure amended well as those of the negative control (polluted with diesel but not amended with manure) had no growth (Table1) among amended pots, seeds sown in poultry manure treated soil generally had higher germination rate than those of cow manure treated soil (Fig 1).

\section{Leaf Count}

The number of leaves per plant increased with weeks. The control plots had the highest number of leaves after fourteen (14) weeks, followed by those of 30\% manure treated plots while those of $20 \%$ treated plots had the least (Table 2). Among manure amend soil, generally poultry manure treated plants had higher number of leaves compared to those of cow manure treated. Positive control plots had the highest mean leaf count (Table 2). 
Statistical analysis showed that mean leaf count differed significantly $(<0.05)$ with weeks. For instance, mean count of leaves for week 12 were significantly higher than those of preceding weeks for both cow dung and poultry dung treated plots at $30 \%$ manure treatment.

However, mean count of leaves for the different manure did not differ from each other at 0.05 level of probability (Table2).

\section{Stem Girth}

The result of the mean stem girth followed a similar trend with those of the aforementioned parameters. The control plots had the highest stem girt followed by $30 \%$ and $20 \%$ manure respectively. Generally plants treated with poultry manure had higher stem girth than those of cow manure (Table 3 ).

Statistical analysis showed that the stem girth of plants grown in the control plants were significantly higher than those of all other treatments (table3).

\section{Plant Height}

Plant height increased with weeks, they were highest among the control plants followed by $30 \%$ and $20 \%$ manure treatment respectively. Plants amended with poultry manure had higher stem height than those grown on cow manure treated soil (Table 4).

Plant height recorded in weeks 12 and 16 were significantly higher than those of all other weeks but do not differ from each other at 0.05 level of probability.

Also, the plant height for the positive control plots were significantly higher than those of the other treatments at 0.05 level of probability (Table4)

\section{Number of Grains per Cob}

\section{Number Of Cobs Per Plant}

Generally plants grown on the control plots had the highest number of kernels, followed by those treated with $30 \%$ manure then $20 \%$ manure respectively.

Among manure treated plants, those fertilized with poultry manure had higher number of kernels than those treated with cow dung (Table 6).

\section{Discussion}

There was no germination in the negative control" i.e (soil+Disel $+0 \%$ treatment). This may be due to the effect of hydrocarbon on the seed. Amakiri and Onofeghara(1983), repoted that oil act as potent contact herbicides on Zea mays, Abelmosehus esculantus and Cassicum frutescens, and that crude oil also affect the germination of seeds of certain plants Like, quackgrass, alafafa and clover. The same was observed at $10 \%$ treatment of both poultry and cow manure. This may be attributed to concentration effect of the diesel oil pollutant and insufficient amount of the organic amendment. At treatment 20 and $30 \%$ cow and poultry manure, there was germination but the duration was longer than that of the positive control i.e. (no diesel $+0 \%$ manure+ soil). It can be suggested that the presence of diesel oil $(250 \mathrm{ml})$ in the soil extends the germination duration of maize seeds even with the addition of organic manure Table 1.

Growth and yield parameters such as Germination count, Mean number of leaves, Plant height and number of grains per plant were higher in poultry manure treated plants than those of cow manure and control plots (without manure).

This observation agrees with the report of Christo et al., (2008). Who suggested that the improved yield of plants treated with poultry manure may be due to suitability of the manure as biostimulant which helps in degrading diesel as well as providing nutrient for the plant.

Yield performance was higher with higher fraction of the manure. This agrees with the report of Onuh et al., (2008). They attributed this observation to increased organic matter content which makes more nutrients available for both plant and microorganisms involved in bioremediation.

\section{Conclution}

The study has shown that diesel contamination affected growth and yield of maize plant adversely.

However, among manure treated plants, those expose to higher fractions of poultry manure were found to perform better than those with equal fractions of cow dung.

Poultry manure can therefore be utilized in diesel polluted soil to grow plants such as maize. 
Effect Of Biostimulation With Organic Amendment On The Growth And Yield Of Maize (Zea Mays) ...

Table 1; Mean Days to Germination of Maize Plant.

\begin{tabular}{llll}
\hline Treatment & \multicolumn{2}{c}{ Days } \\
& & Poultry (g) & Cow Dung (g) \\
\hline -Ve controll & - & - & - \\
+ Ve Controll & 6 & & \\
$10 \%$ & & 0.0 & 0.0 \\
$20 \%$ & & 10 & 13 \\
$30 \%$ & 8 & 11 \\
\hline
\end{tabular}

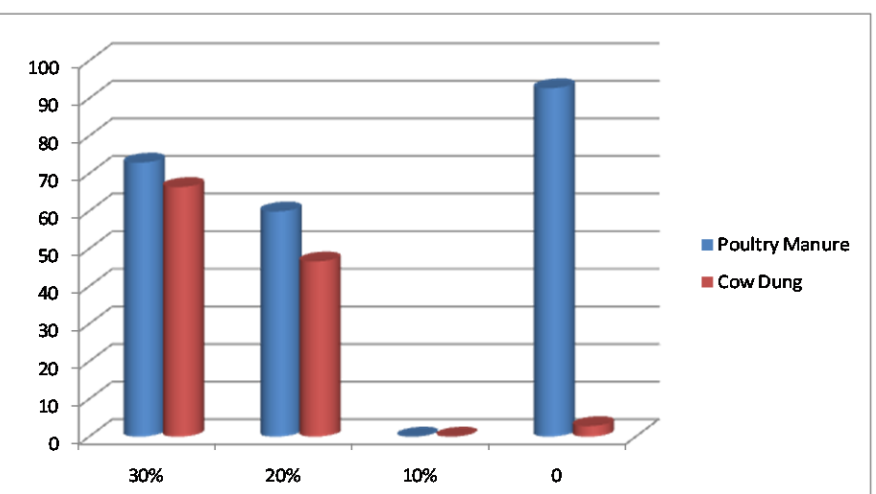

figure 1: Vrean Percentage germination or maize seed in ponted soil.

Table 2: Effect of Maize Treatment on Mean Number of Leaves of Maize Plant Grown in Polluted Soil.

\begin{tabular}{llllcll}
\hline Manure treatment & $\mathbf{5}$ & $\mathbf{6}$ & $\mathbf{9}$ & $\mathbf{1 2}$ & $\mathbf{1 6}$ & LSD \\
\hline Cow manure & 3 & 5 & 7 & 11 & 13 & \\
$0 \%$ & - & - & - & - & - & \\
$10 \%$ & 2 & 4 & 7 & 10 & 10 & \\
$20 \%$ & 3 & 4 & 7 & 10 & 11 & $\mathbf{2 . 8 1}$ \\
$30 \%$ & 3 & 5 & 7 & 11 & 13 & \\
Poultry manure & - & - & - & - & - & \\
$0 \%$ & 2 & 5 & 7 & 10 & 10 & \\
$10 \%$ & 3 & 4 & 8 & 11 & 12 & \\
$20 \%$ & 2.22 & & & & & \\
$30 \%$ & & & & &
\end{tabular}

Table 3: Effect of Biostimulation with Manure on Mean Stem Girth of Maize Plant Grown in Diesel Polluted Soil.

\begin{tabular}{|c|c|c|c|c|c|c|c|}
\hline \multirow{2}{*}{$\begin{array}{l}\text { Manure } \\
\text { Treatment }\end{array}$} & \multicolumn{7}{|c|}{ Weeks } \\
\hline & 3 & 6 & 9 & 12 & 16 & $0 \%$ & LSD \\
\hline \multicolumn{8}{|c|}{ Cow manure } \\
\hline $0 \%$ & 2.3 & 4.6 & 6 & 6.7 & 7.7 & 26.5 & 1.88 \\
\hline $10 \%$ & - & - & - & - & - & - & \\
\hline $20 \%$ & 1.4 & 2.6 & 4.0 & 5.4 & 6.4 & 19.2 & \\
\hline $30 \%$ & 1.7 & 3.0 & 4.7 & 6.0 & 6.8 & 21.5 & \\
\hline \multicolumn{8}{|c|}{ Poultry manure } \\
\hline $0 \%$ & 2.3 & 4.6 & 6 & 6.7 & 7.7 & 26.5 & \\
\hline $10 \%$ & - & - & - & - & - & - & \\
\hline $20 \%$ & 1.8 & 2.9 & 4.0 & 5.5 & 6.6 & 20.2 & \\
\hline $30 \%$ & 2.0 & 3.3 & 5.0 & 6.4 & 7.0 & 23.0 & \\
\hline LSD & 1.48 & & & & & & \\
\hline
\end{tabular}

Table 4: Effect of Maize Treatment on Height of Maize Plant Grown in Polluted Soil.

\begin{tabular}{|c|c|c|c|c|c|c|}
\hline \multirow[t]{2}{*}{ Manure treatment } & \multicolumn{6}{|c|}{ Weeks } \\
\hline & 3 & 6 & 9 & 12 & 16 & LSD \\
\hline \multicolumn{7}{|l|}{ Cow manure } \\
\hline $0 \%$ & 20 & 58 & 111 & 150 & 155 & 8.33 \\
\hline $10 \%$ & - & - & - & - & - & \\
\hline $20 \%$ & 8 & 18 & 44 & 96 & 112 & \\
\hline $30 \%$ & 10 & 22 & 48 & 110 & 118 & \\
\hline \multicolumn{7}{|l|}{ Poultry manure } \\
\hline $0 \%$ & 20 & 58 & 111 & 150 & 155 & \\
\hline $10 \%$ & - & - & - & - & - & \\
\hline $20 \%$ & 10 & 21 & 58 & 110 & 120 & \\
\hline $30 \%$ & 10 & 26 & 67 & 124 & 131 & \\
\hline LSD & 6.58 & & & & & \\
\hline
\end{tabular}


Effect Of Biostimulation With Organic Amendment On The Growth And Yield Of Maize (Zea Mays) ...

Table 6 Number of Grain per Cob

\begin{tabular}{lllll}
\hline Plots & $\begin{array}{l}\text { Manure Treatment } \\
10 \%\end{array}$ & $\mathbf{2 0 \%}$ & $\mathbf{3 0 \%}$ & $\mathbf{0 \%}$ \\
\hline Cow & & & \\
1 & - & 150 & 175 & 101 \\
2 & - & 130 & 189 & 120 \\
3 & - & 170 & 199 & 140 \\
4 & - & 135 & 175 & 145 \\
5 & - & 140 & 160 & 124 \\
Poultry & - & & 101 \\
1 & - & 170 & 210 & 120 \\
2 & - & 183 & 201 & 140 \\
3 & - & 185 & 255 & 145 \\
4 & - & 192 & 202 & 124 \\
5 & & 172 & 214 & \\
\hline
\end{tabular}

\section{References}

[1]. Amakiri, J.O. and Onofeghara, F.A. (1983). Effect of crude oil on the growth of Zea mays, Abelmoschus esculentus and caspsicum frustenscens. Oil and petrolchemical pollution, Vol 1 (3): 1999-2005.

[2]. Adedokun, O.M. and A.E. Ataga, 2007. Effects of amendments and bioaugmentation of soil polluted with crude oil, automotive gasoline, and spent engine oil on the growth of cowpea (Vigna unguiculata L. Walp), Scientific Research and Essay, 2(5): 147-149.

[3]. Agbogidi, O.M., P.G. Eruotor, S.O. Akparobi and G.U. Nnaji, 2007. Effect of crude oil contaminated soil on the mineral elements of maize (Zea mays L.), Journal of Agronomy. 6(1): 188-193.

[4]. Christo, I.E.C.; Madukwe, D.K. and Onuh, M.O. 2008 growth and yield of cowpea (Vigna unguiculata (L.) Walp) As influenced by cultivar and organic manure source in the Humid TropicaL Environment. International Science Research Journal 1 (1): $47-52$.

[5]. Yakubu M. B. (2007) "Biological approach to oil spills remediation in the soil, African Journal of Biotechnology vol. 6 (24) pp 2735-2739.

[6]. Onuh. M.O., Madukwe, D and Ohta, CC (2008 Effect of poultry manure and cow Dung on the physical and chemical properties of crude oil polluted soil. Science world journal. Vol 3 (No2) 45-50).

[7]. Venosa AD, Suidan MT, Wrenn BA, Strohmeier KL, Haines JR, Eberhart BL, King D, Holder E (1996). Bioremediation of an experimental oil spill on the shoreline of Delaware Bay. Environ. Sci. technol.30:1764-1775.

[8]. Miracle, M.D., 1996. Maize in tropical Africa. University of Winconsin Press, Madison.

[9]. Mishra, S, Jyot, J, Kuhad, R.C, Lal, B. (2001). Evaluation of innoculum addition to stimulate in-situ bioremediation of oily sludge contaminated soil. App. Eviron. Microbiol.67: 1675-1781.

[10]. Mckee, K.L, Mendelssohn, I.A. (1995). A review of the methods and bioremediation in wetlands. Report to the marine spill Response cooperation, Washington.D.C. 31.

[11]. Shekwolo P. D (2005) Oil production and sustainable environmental management: SPDC experience. In: Mogbo IN, Oladimeji AA, Jonah S. Okoli GA (eds) Current Trends in Science and science education. Federal University of Technology, Minna Conference, Pp xxxvi-ivii.

[12]. Swannel, R.P.J., Lee; Kenneth; McDonagh,Modeleine (1996) Field Evaluation of Marine Oil Spill. Bioremediation Microbiology Reviews 60; 342-368. 